\title{
Incorporation of thymidine into onion root meristematic cell nuclei in presence of hydroxyurea and its role in recovery of mitotic activity*
}

\author{
H. HABDAS
}

Electron Microscopy Laboratory, Institute of Botany, Warsaw University, Warsaw

(Received: October 10, 1977)

\begin{abstract}
Hydroxyurea treatment of onion roots induced mitotic block which was released by transfer of bulbs to water, and also to some extent by addition of cold or ${ }^{3} \mathrm{H}$-thymidine to hydroxyurea solutions. In presence of hydroxyurea there was noted very intense incorporation of ${ }^{3} \mathrm{H}$-thymidine into cell nuclei, giving labelling index of $40-70 \%$. However, all the mitotic figures appearing in presence of hydroxyurea and ${ }^{3} \mathrm{H}$-thymidine were unlabelled. On the other hand, labelled mitotic figures were obtained when roots incubated with ${ }^{3} \mathrm{H}$-thymidine in presence of hydroxyurea had been transferred to water. Incorporation of ${ }^{3} \mathrm{H}$-uridine was unaffected by hydroxyurea. The results show that hydroxyurea arrests onion root meristematic cells, either in the $\mathrm{S}$ phase and the $\mathrm{G}_{2}$ phase. Enhanced incorporation of ${ }^{3} \mathrm{H}$-thymidine in the presence of hydroxyurea, and release by added thymidine of the mitotic block indicate that hydroxyurea induces in onion root meristematic cells a particular shortage of thymidylate.
\end{abstract}

\section{INTRODUCTION}

Hydroxyurea is a potent inhibitor of DNA synthesis in bacteria (R o s en kr a n z et al., 1966; J y s s u m, 1973), in yeasts (S l a t e r, 1973), in protozoa (Buetow and Mego, 1967; In jeyan et al., 1974), in mammalian cells in vitro (Mohler, 1964; S inclair, 1965, 1967; Manso-Martinez and Frank, 1972; Miyamoto et al., 1976) and in mammalian cells in situ ( $\mathrm{Schwartz}$ et al., 1965; Gillette

* This work was supported by the Polish Academy of Sciences within the project 09.7 .3 . 
et al., 1970; R a j ew sky et al., $1971 \mathrm{a}, \mathrm{b}$; R a b e s et al., 1974; N e c a s and Neuwirt, 1976). Moreover, hydroxyurea has proved to arrest duplication of viral DNA (Ros en kranz et al., 1973; Mag nus son, 1973).

Also plant cells and tissues are sensitive to hydroxyurea. So, effects of hydroxyurea were investigated in algae (H eilporn-Pohl and Limbosh-Rolin, 1969; W a n k et al., 1972), in Haplopappus gracilis, Compositae (Kihlman et al., 1966), in root meristems of Vicia faba (K i h l man et al., 1966; H a ll et al., 1968; Od mark, 1971) and Allium sativum (Brulfert and Deysson, 1973) in Nicotiana tabacum tissue culture (Rennert, 1977 a; Maciejew ska-P ot a pczykowa et al., 1970; Bilecka, $1975 \mathrm{a}, \mathrm{b})$, in Helianthus annuus tissue culture (Rennert, $1977 \mathrm{~b}$ ) and in Cucumis sativum seeds and leaves (R ennert and Knypl, 1971, 1972).

The primary biochemical effect of hydroxyurea is inhibition of ribonucleoside diphosphate reductase (Adams and Lindsay, 1967; Young et al., 1967; Krak of et al., 1968; Moore, 1969; S in ha and Snustad, 1972; Theiss and Fischer, 1976). In this way, hydroxyurea-treated cells become depleted of deoxyribonucleotides indispensable for DNA synthesis, what makes S phase cells particularly sensitive to action of hydroxyurea (S i n c la i r, 1965, 1967).

The present study was designed to examine incorporation of ${ }^{3} \mathrm{H}$-thymidine in onion root meristems in presence of hydroxyurea, and its effects on the meristematic mitotic activity.

\section{MATERIALS AND METHODS}

R o ot culture. Onion bulbs (Allium cepa L., var. Wolska-Szepietowski) were obtained from the Gardening Institute, Skierniewice. Growth of roots was induced by placing the bulbs in necks of conical $200 \mathrm{ml}$ flasks with boiled and filtered spring water. When roots were $0.5-1 \mathrm{~cm}$ long, the bulbs were placed (in groups of six) on nylon netting over 2.81 glass crystallizers. The water was intensively aerated, and changed every day. After four days, most roots reached $4-5 \mathrm{~cm}$. Shorter and longer roots were removed before subsequent treatment with hydroxyurea. The cultures were grown in darkness at room temperature.

Chemicals and radiochemicals. Hydroxyurea (HU) was purchased from Calbiochem (San Diego). Cold thymidine (TdR) was from British Drug Houses. ${ }^{3} \mathrm{H}-$ Thymidine- $\left(5-\mathrm{C}^{3} \mathrm{H}_{3}\right), 19.69 \mathrm{Ci} / \mathrm{mmole}$, $1 \mathrm{mCl} / \mathrm{ml}, 12.3 \mu \mathrm{g} / \mathrm{ml}$, and ${ }^{3} \mathrm{H}$-uridine, $21.5 \mathrm{Ci} / \mathrm{mmole}, 1 \mathrm{mCi} / \mathrm{ml}$, were purchased from Institute for Research, Preparation and Application of Radioisotopes, Prague (Czechoslovakia). ${ }^{3} \mathrm{H}$-Thymidine and ${ }^{3} \mathrm{H}$-uridine were diluted with boiled spring water to activity of $5 \mu \mathrm{Ci} / \mathrm{ml}$. 
Incubation of roots. Each onion bulb was mounted at the top of a glass vessel with $40 \mathrm{ml}$ of $2.6 \mathrm{mM}(0.2 \mathrm{mg} / \mathrm{l})$ hydroxyurea solution. Next, it was replaced by: (A), water ( $24 \mathrm{hrs} \mathrm{HU}-48 \mathrm{hrs} \mathrm{H}_{2} \mathrm{O}$ ); (B), ${ }^{3} \mathrm{H}$-thymidine $(5 \mu \mathrm{Cl} / \mathrm{ml})$ in $2.6 \mathrm{mM}$ hydroxyurea $(24 \mathrm{hrs} \mathrm{HU}-$ $24 \mathrm{hrs}{ }^{3} \mathrm{H}-\mathrm{TdR}+\mathrm{HU}$ ); (C) and (D), O. $3 \mathrm{mM}$ and $0.03 \mathrm{mM}$ cold thymidine in $2.6 \mathrm{mM}$ hydroxyurea ( $24 \mathrm{hrs} \mathrm{HU}-24 \mathrm{hrs} \mathrm{TdR+HU})$; (E) and (F), ${ }^{3} \mathrm{H}$-thymidine $(5 \mu \mathrm{Ci} / \mathrm{ml})$ in $2.6 \mathrm{mM}$ hydroxyurea for $6 \mathrm{hrs}$, and subsequently $2.6 \mathrm{mM}$ hydroxyurea alone $\left(24 \mathrm{hrs} \mathrm{HU}-6 \mathrm{hrs}{ }^{3} \mathrm{H}-\mathrm{TdR}+\mathrm{HU}\right.$ - $18 \mathrm{hrs} \mathrm{HU})$ or water $\left(24 \mathrm{hrs} \mathrm{HU}-6 \mathrm{hrs}{ }^{3} \mathrm{H}-\mathrm{TdR}+\mathrm{HU}-18 \mathrm{hrs}\right.$ $\mathrm{H}_{2} \mathrm{O}$ ); (G), ${ }^{3} \mathrm{H}$-thymidine in water for $6 \mathrm{hrs}$ and next water $(24 \mathrm{hrs} \mathrm{HU}$ $6 \mathrm{hrs}{ }^{3} \mathrm{H}-\mathrm{TdR}+\mathrm{H}_{2} \mathrm{O}-18 \mathrm{hrs} \mathrm{H}_{2} \mathrm{O}$ ). Each experimental treatment was performed twice. At time points as indicated, two roots were collected from each bulb for examination.

Autoradiography and microscope examination. The roots were fixed "with aceto-alcohol $(1: 3 \mathrm{v} / \mathrm{v})$ and stained with $0.2 \%$ acetoorceine. Squash preparations were made. Autoradiography was performed by the striping film method, using Kodak AR-10 plates. The preparations were exposed for 3 weeks at $4^{\circ} \mathrm{C}$. The global mitotic index, the index of labelled mitoses and index of labelled nuclei were scored by counting 1000 cells from each root.

\section{RESULTS}

Incubation of onion in $2.6 \mathrm{mM}$ hydroxyurea $(0.2 \mathrm{mg} / \mathrm{ml})$ for $24 \mathrm{hrs}$ proved to reduce the mitotic index in meristems to below $1 \%$, while in untreated controls, it amounted to $14-24 \%$ (Fig. 1). The hydroxyurea-induced mitotic block was released by transfer of roots to water, and a distinct peak of mitotic activity, indicative of synchronization of meristematic cells, exceeding considerably the mitotic index in untreated roots, was found after removal of hydroxyurea (Fig. 1).

It claims attention that mitotic activity proved to be also induced in presence of hydroxyurea by addition of 0.03 and $0.3 \mathrm{mM}$ cold thymidine (Fig. 2) or $0.25 \mu \mathrm{M}{ }^{3} \mathrm{H}$-thymidine (Fig. 3, 4a), while in meristems treated in parallel with hydroxyurea in absence of exogenous thymidine, the mitotic index still remained below $1 \%$ (Fig. 2).

Furthermore, autoradiography has revealed intense incorporation of ${ }^{3} \mathrm{H}$-thymidine into many cell nuclei when roots were incubated with it in the presence of hydroxyurea, resulting in the labelling index of $40-70 \%$ (Fig. 3, 4a-c). It has to be emphasized that labelling of individual nuclei was much more intense in presence of hydroxyurea (Plate I, photos 4,6) than in controls (Plate I, photos 3, 5).

In spite of the intense labelling of nuclei and prolongation of incubation for further $24 \mathrm{hrs}$, all the mitotic figures observed in the presence 
of hydroxyurea supplemented with ${ }^{3} \mathrm{H}$-thymidine did not contain any label (Plate II, photos 1, 2). On the other hand, labelled mitotic figures were obtained only when roots preincubated with ${ }^{3} \mathrm{H}$-thymidine in the

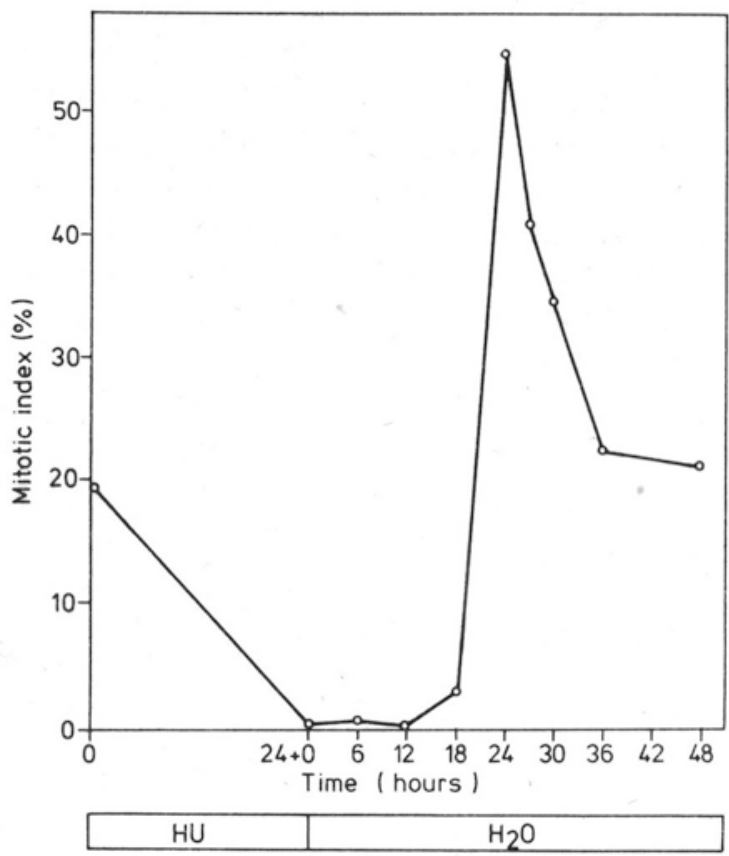

Fig. 1. Synchronization of meristematic mitotic activity in onion roots transferred to water after $24 \mathrm{hrs}$ incubation with $2.6 \mathrm{mM}$ hydroxyurea

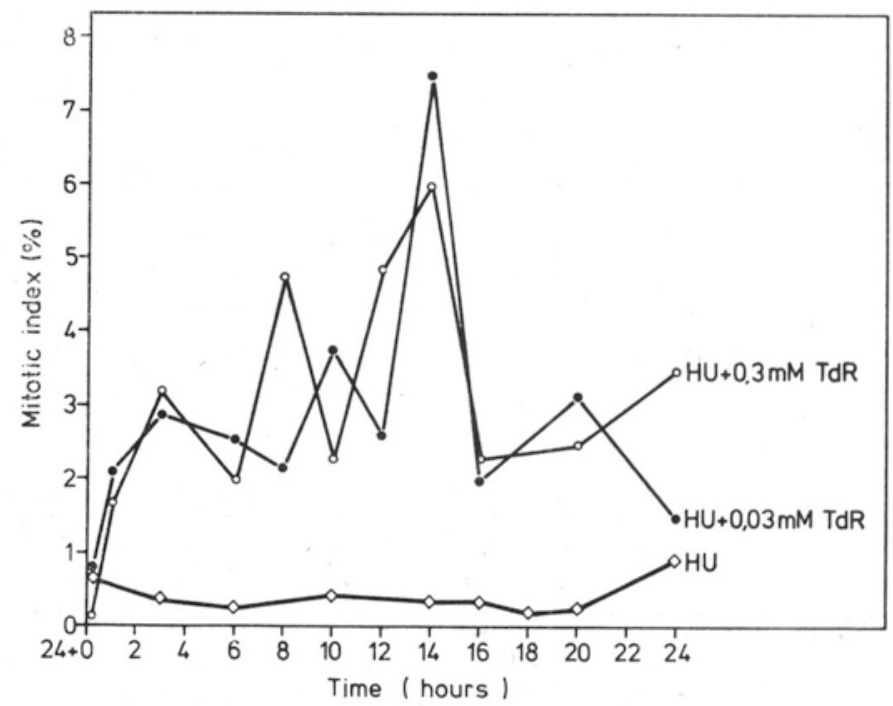

Fig. 2. Release of mitotic block in onion root meristems after transfer of roots incubated for $24 \mathrm{hrs}$ with $2.6 \mathrm{mM}$ hydroxyurea to $0.03 \mathrm{mM}$ or $0.3 \mathrm{mM}$ thymidine in $2.6 \mathrm{mM}$ hydroxyurea 


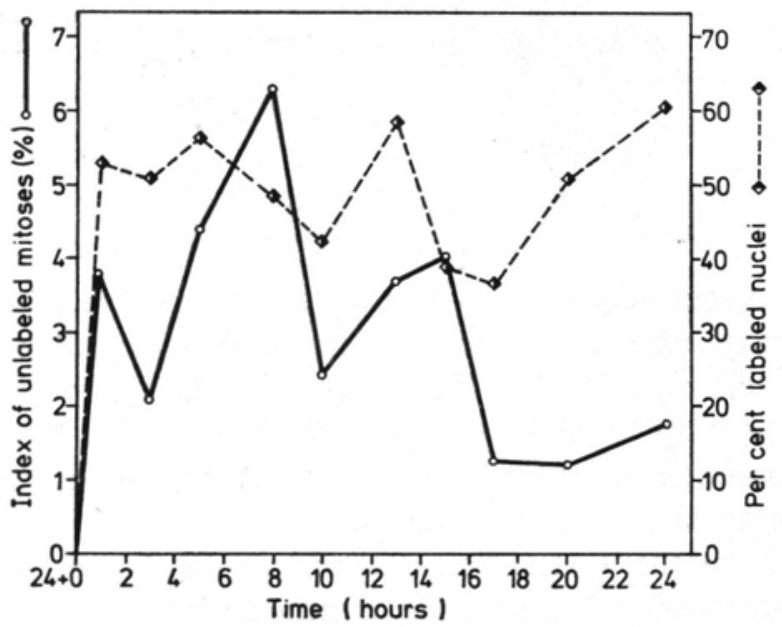

Fig. 3. Index of unlabelled mitoses and index of labelled nuclei after transfer of onion roots, incubated for $24 \mathrm{hrs}$ with $2.6 \mathrm{mM}$ hydroxyurea, to solutions of ${ }^{3} \mathrm{H}$-thymidine $(0.25 \mu \mathrm{M}, 60 \mathrm{ng} / \mathrm{ml}, 5 \mu \mathrm{Ci} / \mathrm{ml})$ in $2.6 \mathrm{mM}$ hydroxyurea. No labelled mitoses were found

presence of hydroxyurea had been transferred to water (Plate II, photos 3-5). First labelled divisions appeared under these conditions $12 \mathrm{hrs}$ after removal of hydroxyurea.

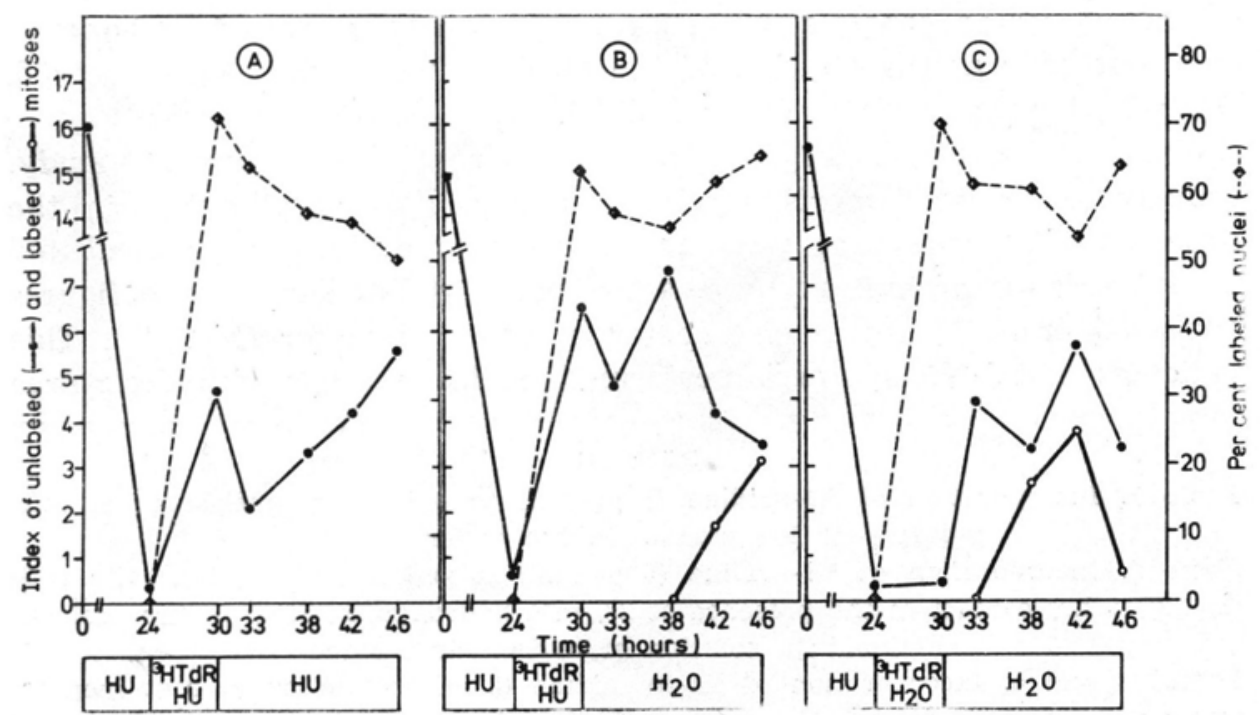

Fig. 4. Indices of labelled nuclei, unlabelled mitoses and labelled mitoses in onion root meristems treated for $24 \mathrm{hrs}$ with $2.6 \mathrm{mM}$ hydroxyurea, and subsequently transferred to: (a), HU with ${ }^{3} \mathrm{H}-\mathrm{TdR}$ for $6 \mathrm{hrs}$, and then $\mathrm{HU}$ alone; (b), HU with ${ }^{3} \mathrm{H}-\mathrm{TdR}$ for $6 \mathrm{hrs}$, and then water; (c), ${ }^{3} \mathrm{H}-\mathrm{TdR}$ in water for $6 \mathrm{hrs}$, and then water alone 
Uptake of ${ }^{3} \mathrm{H}$-uridine by the meristematic cells has proved to be unaffected by hydroxyurea (Plate I, photos 1,2).

\section{DISCUSSION}

Rather unexpectively, during prolonged incubation with hydroxyurea there was noted intensive incorporation of ${ }^{3} \mathrm{H}$-thymidine to onion root meristematic cell nuclei (Plate I, photos 4,6). Occurence of not labelled cells besides heavily labelled ones indicated that the ${ }^{3} \mathrm{H}$-thymidine uptake in the presence of hydroxyurea was not due to repair DNA synthesis, but reflected the S-phase process.

It has been recently established that mammalian cells in culture, in spite of extreme reduction of DNA synthesis by hydroxyurea, preserve the ability to synthetize short fragments of DNA (Coyle and Straus s, 1970; B rown and Wheatley, 1974; Fu jiwara, 1975; Martin et al., 1976; W a lters et al., 1976), and the same applies to duplication of viral DNA ( $\mathrm{Magnuss}$ an, 1973). This phenomenon is considered to reflect relatively low sensitivity to shortage of deoxyribonucleotides of the DNA polymerase acting at first stages of DNA synthesis, while the gap-filling DNA polymerase is highly sensitive ( $\mathrm{M}$ a r t i n, 1976). Moreover, W a l ters et al. (1976) have shown that hydroxyurea permits $G_{1}$-phase cells to enter the $S$ phase at the same time and rate as the untreated controls, while previously, hydroxyurea was believed to arrest cells at the $G_{1}$ side of the $G_{1} / S$ boundary ( $\mathrm{S} \mathrm{in} \mathrm{c} \mathrm{la} \mathrm{ir,} \mathrm{1965,}$ 1967; T o bey and Gris s ma n, 1972).

The above seems to apply rather well to results of the present study. Namely, onion root meristematic cells with DNA synthetized in the presence of hydroxyurea were not capable to divide unless incubated in the absence of hydroxyurea, since the first labelled mitotic figures appeared only $12 \mathrm{hrs}$ after transfer of roots to water (Fig. 4b). This indicates that DNA synthesis performed in the presence of hydroxyurea

P L A T E I

Photo 1. Incorporation of ${ }^{3} \mathrm{H}$-uridine $(5 \mu \mathrm{Ci} / \mathrm{ml})$ to onion root meristematic cells during $12 \mathrm{hrs}$ contact in the water medium

Photo 2. Incorporation of ${ }^{3} \mathrm{H}$-uridine $(5 \mu \mathrm{Ci} / \mathrm{ml})$ to onion root meristematic cells during $12 \mathrm{hrs}$ contact in the presence of $2.6 \mathrm{mM}$ hydroxyurea after $24 \mathrm{hrs}$ preincubation in a solution of hydroxyurea alone

Photos 3 and 5 . Incorporation of ${ }^{3} \mathrm{H}$-thymidine $(5 \mu \mathrm{Ci} / \mathrm{ml})$ to onion root meristematic cell nuclei during $6 \mathrm{hrs}$ contact in the absence of hydroxyurea, in bulbs not pretreated with hydroxyurea

Photos 4 and 6. Incorporation of ${ }^{3} \mathrm{H}$-thymidine $(5 \mu \mathrm{Ci} / \mathrm{ml})$ to meristematic cell nuclei of onion roots pretreated for $24 \mathrm{hrs}$ with $2.6 \mathrm{mM}$ hydroxyurea, and subsequently incubated with ${ }^{3} \mathrm{H}$-thymidine for $6 \mathrm{hrs}$ in the presence of hydroxyurea The cells were stained with aceto-orceine. Exposition time -3 weeks. Photos $1-4, \times 800$. 

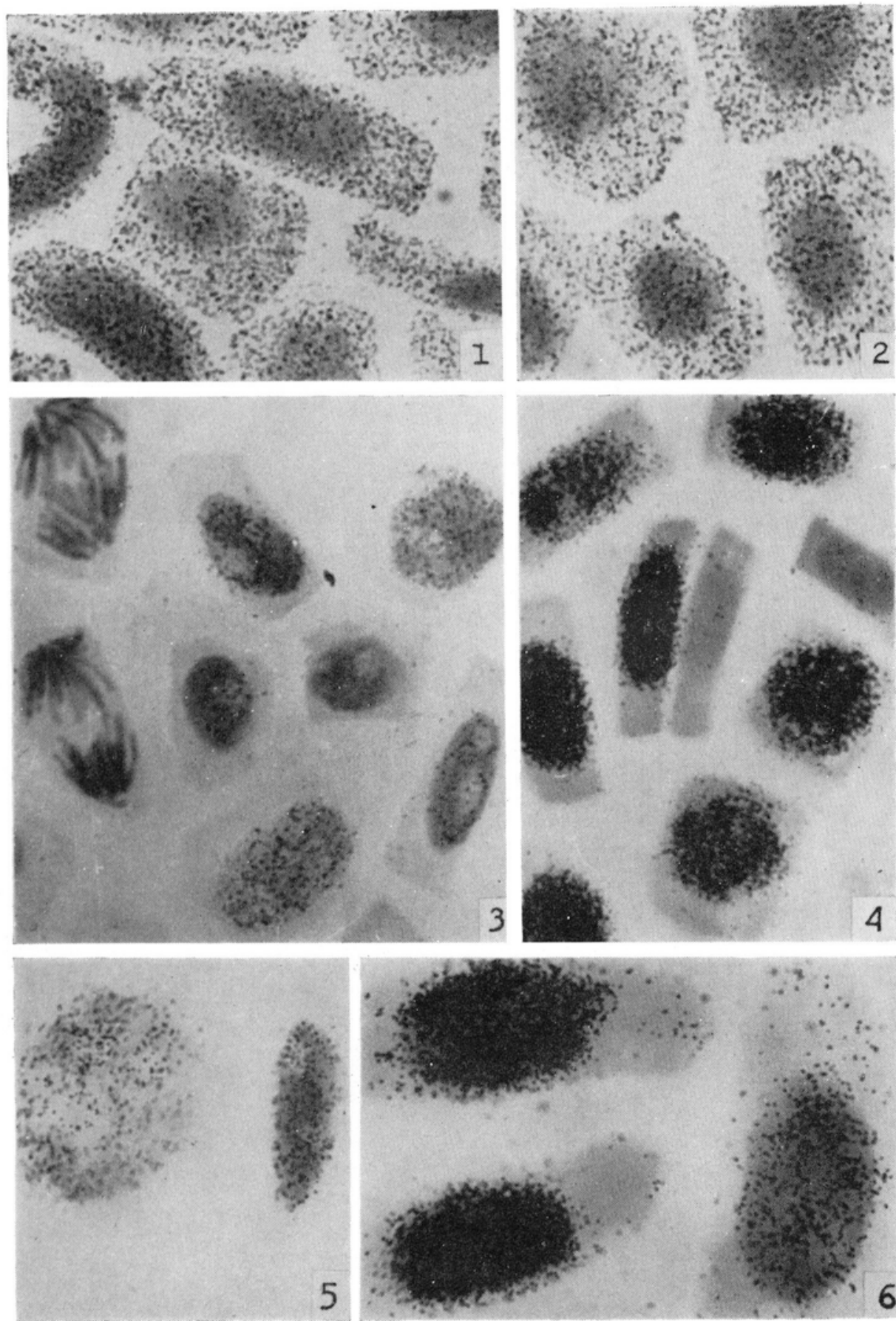
P L A T I I

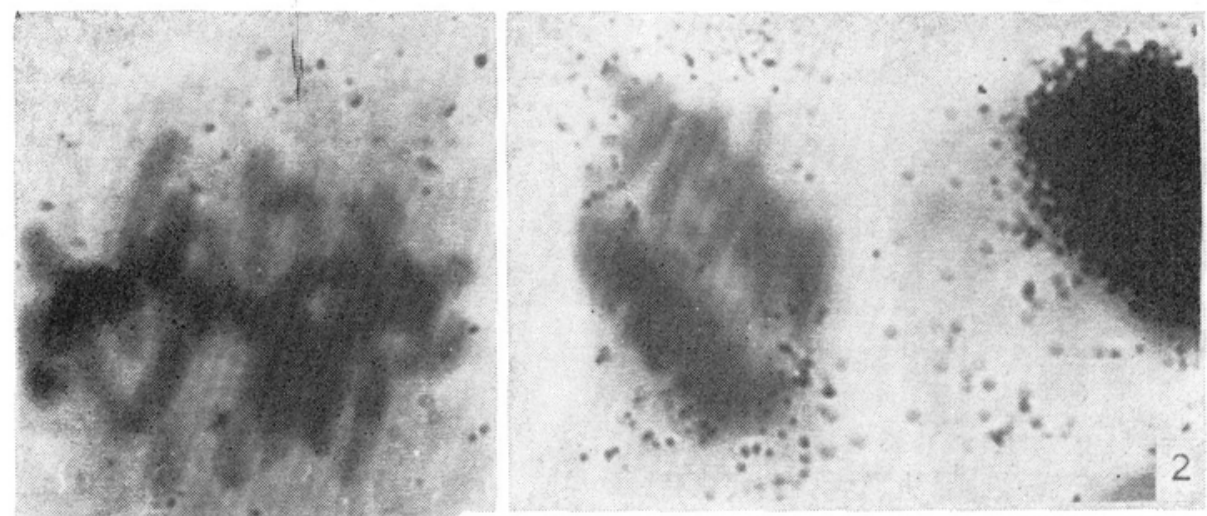

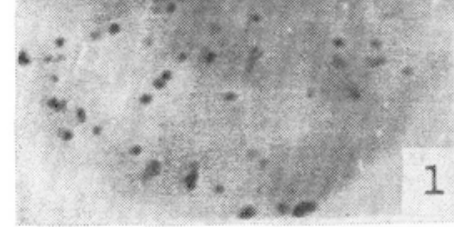
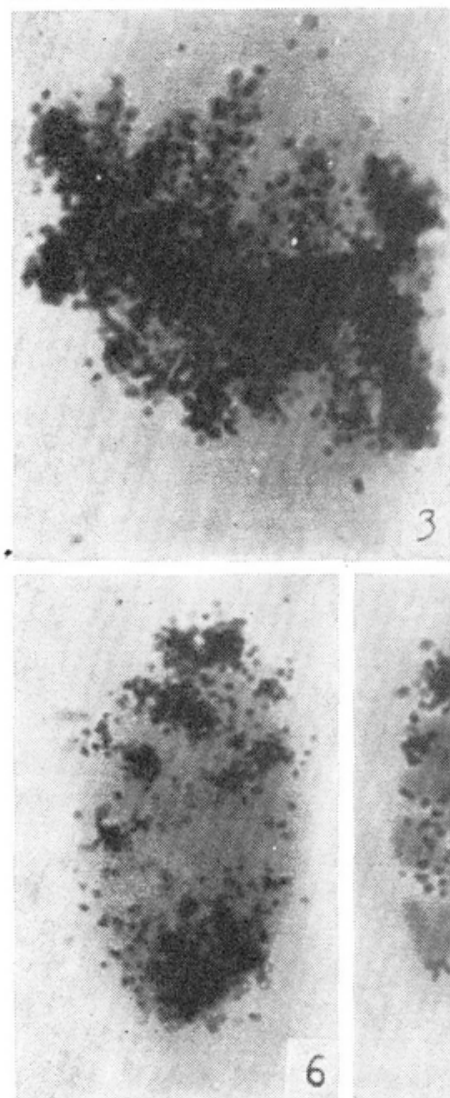

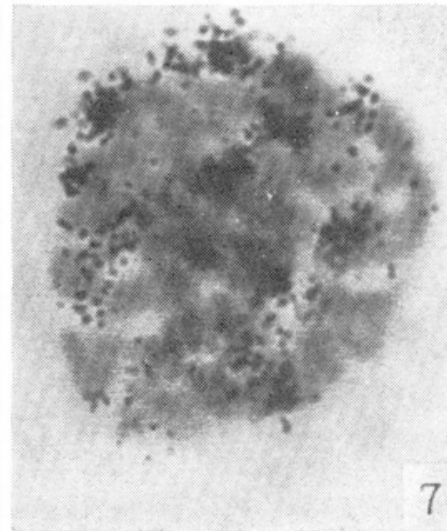

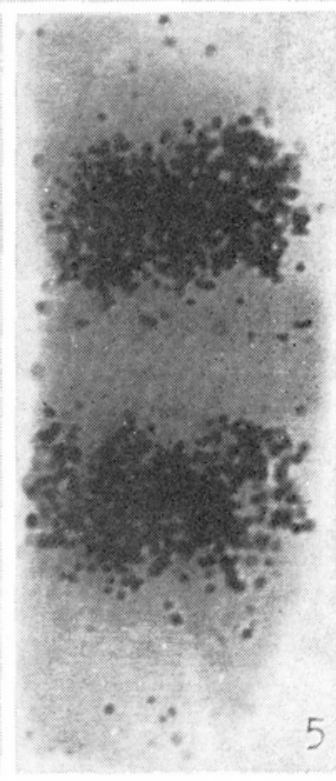

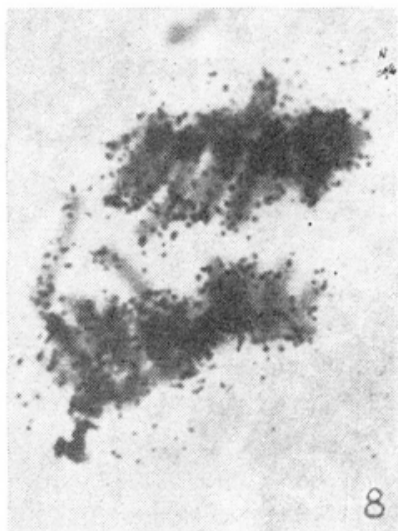


had to be completed in its absence. Furthermore, autoradiography has shown discontinous labelling of some mitotic figures and irregular distribution of the label in some nuclei (Plate II, photos 6-8), what might relate to synthesis of short fragments of DNA.

High enhancement of ${ }^{3} \mathrm{H}$-thymidine incorporation to onion root meristematic cell nuclei, found in the presence of hydroxyurea, has to be emphasized (Plate I, photos 4, 6). Some potentiation of ${ }^{3} \mathrm{H}$-thymidine incorporation by hydroxyurea treatment was also noted in mouse fibroblast cell cultures (A d a m s and Linds a y, 1967) and in cultures of Crithidia sp., Haemoflagellata (In jeyan et al., 1974). Moreover, enhancement of ${ }^{3} \mathrm{H}$-thymidine incorporation following specific arrest of thymidylate synthesis with 5-fluorodeoxyuridine or methotrexate ( $\mathrm{R} \mathrm{u}$ bin i, 1966; Roberts and W a dinsky, 1968; B o ge $\mathrm{nhagen}$ and Clayton, 1976) has to be taken into account, since it clearly shows that shortage of endogenous thymidylate reflects in increased incorporation of exogenous thymidine.

At this place, it has to be mentioned that thymidine kinase is not inhibited by hydroxyurea (A d a m s and Lindsay, 1967).

In view of the above data, high potentiation of incorporation of ${ }^{3} \mathrm{H}$-thymidine, noted in onion root meristems in the presence of hydroxyurea, may be considered to reflect a selective arrest of deoxyuridylate (dUMP) formation, the precursor of thymidylate (TMP). However, the question arises on source of the remaining three deoxyribonucleotides, since their formation in other biological objects seems to be generally inhibited, except for some microorganisms (e.g. Lactobacillus leichmanni) reducing ribonucleotides at the triphosphate level with the cobamide dependent reductase (E 1 f o $\mathrm{r} d, 1968$ ).

Induction of unlabelled divisions in the presence of hydroxyurea was another effect of exogenous thymidine (Fig. 2, 3, 4a). Absence of the label in mitotic figures indicates that the cells had passed the $\mathrm{S}$ phase before the contact with ${ }^{3} \mathrm{H}$-thymidine. Thus, they were arrested by hydroxyurea in the $\mathrm{G}_{2}$ phase. This effect of hydroxyurea was found to

PLATE II

Photos 1 and 2. Non-labelled mitotic figures induced in the presence of $2.6 \mathrm{mM}$ hydroxyurea by $6 \mathrm{hrs}$ incubation with $0.25 \mu \mathrm{M}{ }^{3} \mathrm{H}$-thymidine $(5 \mu \mathrm{Cl} / \mathrm{ml})$ after previous $24 \mathrm{hrs}$ treatment with hydroxyurea

Photos 3-5. Labelled mitotic figures in meristems of onion roots pretreated for $24 \mathrm{hrs}$ with $2.6 \mathrm{mM}$ hydroxyurea, incubated subsequently with ${ }^{3} \mathrm{H}$-thymidine $(5 \mu \mathrm{Ci} / \mathrm{ml})$ in the presence of hydroxyurea for $6 \mathrm{hrs}$, and finally transferred to water for $12 \mathrm{hrs}$

Photos 6-8. Irregular distribution of the label in nuclei (Photo 6) and discontinous labellnng of mitotic figures (Photos 7 and 8 ) in meristems of onion roots treated for $24 \mathrm{hrs}$ with $2.6 \mathrm{mM}$ hydroxyurea, incubated subsequently with ${ }^{3} \mathrm{H}$-thymidine

$(5 \mu \mathrm{Ci} / \mathrm{ml})$ in the presence of hydroxyurea, and finally transferred to water

The cells were stained with aceto-orceine. Exposition time -3 weeks. Magnification $\times 1500$ 
be released by minute amounts of exogenous thymidine, in spite of continued treatment of onion roots with hydroxyurea. The latter finding indicates that some residual DNA synthesis, not revealed by autoradiography, occurs in meristematic cells during the $\mathrm{G}_{2}$ phase.

In view of the presented results, it may be concluded that hydroxyurea arrests onion root meristematic cells both in the $\mathrm{S}$ phase and the $\mathrm{G}_{2}$ phase by inducing a particular shortage of thymidylate, released by addition of thymidine to the incubation medium.

\section{Acknowledgments}

The author wishes to express sincere gratitude to Professor $\mathrm{Henryk}$ Tele ży ński for suggesting the theme and helpful discussion throughout the course of this research.

\section{REFERENCES}

A dams R. L. P., Lindsay J. G., 1967. Hydroxyurea: Reversal of inhibition and use as a cell-synchronizing agent. J. Biol. Chem. 242: 1314-1317.

$\mathrm{B} \mathrm{i}^{4} \mathrm{l}$ e ck a A., 1975a. Influence of hydroxyurea on nucleic acid content and ${ }^{3} \mathrm{H}$-uridine incorporation in callus and tumorous tobacco tissues cultured in vitro. Acta Soc. Bot. Pol. 44: 393-405.

Bilecka A., 1975b. Effect of hydroxyurea on the protein content and synthesis in normal and tumorous tobacco tissues cultured in vitro. Folia Histochem. Cytochem. 13: 139-150.

Bo'genhagen D., Cla y ton D., 1976. Thymidylate nucleotide supply for mitochondrial DNA synthesis in mouse L-cells. Effect of 5-fluorodeoxyuridine and methotrexate in thymidine kinase plus and thymidine kinase minus cells. J. Biol. Chem. 251: 2938-2944.

B r own J. S., Wh eatley D. N., 1974. DNA synthesis in the presence of hydroxyurea. Brit. J. Cancer 30: 173. (Abstract).

Brulfert A., Deysson G., 1973. Synchronisation des divisions méristématique d'Allium sativum L. par l'hydroxyurée. Conditions d'application à l'analyse cinetique des effects cytoxiques. Annales pharmaceutiques franc. 31 : $19-27$.

Buetow D. E., Mego J. L., 1967. Hydroxyurea inhibition of greening, macromolecule synthesis and cell division in Euglena gracilis. Biochim. Biophys. Acta 134: $395-401$.

Coyle M. B., Strauss B., 1970. Cell killing and the accumulation of breaks in the DNA of HE-2 cells incubated in the presence of hydroxyurea. Cancer Res. 30: 2314-2319.

E 1 f ord H. L., 1968. Effect of hydroxyurea on ribonucleotide reductase. Biochem. Biophys. Res. Commun. 33: 129-135.

Fujiwara Y., 1975. Postreplication repair of ultraviolet damage to DNA, DNA-chain elongation, and effects of metabolic inhibitors in mouse L-cells. Biophys. J. 15: 403-415.

Gillette E. L., Withers H. R., Tannock I. F., 1970. The age sensitivity of epithelial cells of mouse small intestine. Radiology 96: 639-643.

Hall E. J., Brown J. M., Cavanagh J. J., 1968. Radiosensitivity and the oxygen effect measured at different phases of the mitotic cycle using synchronously dividing cells of the root meristem of Vicia faba. Rad. Res. 35: $622-634$. 
Heilporn-Pohl V., Limbosh-Rolin S., 1969. Effects de l'hydroxyurée sur Acetabularia mediterrenea. Biochim. Biophys. Acta 174: 220-229.

In jey a n H. S., M e erovitch E., M c'La u g h l in J., 1974. Anomalous enhancing effect of hydroxyurea on DNA synthesis. Life Sciences 14: 1687-1693.

Jys sum K., 1973. Cell division after inhibition of DNA and protein synthesis in Neisseria meningitidis. Acta pat. microbiol. scand. Sect. B 81: 127-137.

Kihlman S. A., Eriksson T., Odmark G., 1966. Effects of hydroxyurea on chromosomes, cell division and nucleic acid synthesis in Vicia faba. Hereditas 55: $386-397$.

Krak off I. H., Brown N. C., Reichard P., 1968. Inhibition of ribonucleoside diphosphate reductase by hydroxyurea. Cancer Res. 28: 1559-1565.

Maciejewska-Potapczykowa W., Rennert A., Bilecka A., 1970. Influence of hydroxyurea on growth and nitrogen fraction content in callus and tumorous tissues of Nicotiana tabacum cultured in vitro. Zesz. Nauk. UMK N. Mat.-Przyr. Biol. 13: 257-262.

Magnusson G., 1973. Hydroxyurea-induced accumulation of short fragments during polyoma DNA replication. I. Characterization of fragments. II. Behavior during incubation of isolated nuclei. J. Virol. 12: 600-608, 609-615.

Manso-Martinez R., Frank W., 1972. Die Wirkung von Hydroxyharnstoff auf die DNA-Synthese embryonaler Rattenzellen in Kultur. Zeit. Naturforsch. (B) 27b: 1500-1507.

Martin R. F., Radford I., Pardee M., 1976. Accumulation of short DNA fragments in hydroxyurea treated mouse L-cells. Biochem. Biophys. Res. Commun. 74: 9-15.

Mi y a moto T., W a t a n a b e M., T a kabe Y., T erasi ma T., 1976. Synchrony of Burkitt lymphoma cells induced by hydroxyurea. Cell Structure and Function 1: 177-185.

Mohler W. C., 1964. Cytotoxicity of hydroxyurea (NCS-32065) reversible by pyrimidine deoxyribosides in a mammalian cell line grown in vitro. Cancer Chemoth. Rep. 34: 1-6.

M oore E. C., 1969. The effects of ferrous ion and dithioerythritol on inhibition by hydroxyurea of ribonucleotide reductase. Cancer Res. 29: 291-295.

Necas E., Neuwirt J., 1976. Control of haemopoietic stem cell proliferation by cells in DNA synthesis. Brit. J. Haemat. 33: 395-400.

Odmark G., 1971. Effects of hydroxyurea on the synthesis of deoxycytidine phosphate and the uptake of nucleosides in excised root tips of Vicia faba. Physiol. Plant. 25: 158-163.

R a bes H. M., I s e le r G., Tuczek H. V., K e r ler R., 1974. Increased synchrony of DNA synthesis in regenerating rat liver after continous infusion of hydroxyurea. Experientia 30: 1116-1117.

Rajewsky M. F., Hülser D. F., F abricius E., 1971a. Untersuchungen zur Synchronisation in vivo: Temporare Inhibition der DNA-Synthese durch Hydroxyharnstoff in normalen und malignen Säugerzellsystemen. Z. Krebsforsch. 76: $266-292$.

Rajewsky M. F., Fabricius E., Hulser D. F., 1971b. Synchronisation in vivo: Temporary inhibition of DNA synthesis in the rat embryo with hydroxyurea. Exp. Cell Res. 66: 489-492.

R ennert A., 1977a. Metabolic aspects of growth in HU-treated crown-gall tissue cultures. I. Nicotiana tabacum. Acta Soc. Bot. Pol. 46: 79-99.

Rennert A., 1977b. Metabolic aspects of growth in HU-treated crown-gall tissue cultures. II. Helianthus annuus. Acta Soc. Bot. Pol. 46: 101-118. 
Rennert A., Knypl J. S., 1971. Hamowanie syntezy chlorofilu i RNA w izolowanych liścieniach ogórka przez N-hydroksymocznik. Acta Soc. Bot. Pol. 40: $669-679$.

Rennert A., Knypl J. S., 1972. Wpływ N-hydroksymocznika na kiełkowanie nasion, wzrost izolowanych liści ogórka i innych biotestów. Zesz. Nauk. UŁ. N. Mat.-Przyr. (s. II) 40: 101-114.

Roberts D., Wodinsky I., 1968. On the poor correlation between the inhibition by methotrexate dihydrofolate reductase and deoxynucleoside incorporation into DNA. Cancer Res. 28: 1955-1962.

Ros enkranz H. S., Garro A. J., Levy J. A., Carr H. S., 1966. Studies with hydroxyurea. I. The reversible inhibition of bacterial DNA synthesis and the effect of hydroxyurea on the bactericidal action of streptomycin. Biochim. Biophys. Acta 114: 501-515.

Ros enkranz H. S., Gutter B., Becker Y., 1973. Studies on the developmental cycle of Chlamydia trachomatis: Selective inhibition by hydroxyurea. J. Bact. 115: $682-690$.

Rubini J. R., 1966. In vitro DNA labeling of bone marrow and leukemic blood leucocytes with tritiated thymidine. II. ${ }^{3} \mathrm{H}-\mathrm{Thymidine}$ biochemistry in vitro. J. Lab. Clin. Med. 68: 566-576.

Schwartz H. S., Gar of a 10 M., Sternberg S. S., Philips F. S., 1965. Hydroxyurea: Inhibition of deoxyribonucleic acid synthesis in regenerating liver of rats. Cancer Res. 25: 1867-1870.

Sinclair W. K., 1965. Hydroxyurea: Differential lethal effects on cultured mammalian cells during the cell cycle. Science 150: 1729-1731.

Sinclair W. K., 1967. Hydroxyurea: Effects on Chinese hamster cells grown in culture. Cancer Res. 27: 297-308.

Sinha N. K., Snustad D. P., 1972. Mechanism of inhibition of deoxyribonucleic acid synthesis in Escherichia coli by hydroxyurea. J. Bact. 112: 13211333 .

S 1 a te r M. L., 1973. Effect of reversible inhibition of deoxyribonucleic acid synthesis on the yeast cycle. J. Bact. 113: 263-270.

Theis s J. C., Fisher G. A., 1976. Inhibition of intracellular pyrimidine ribonucleotide reduction by deoxycytidine, arabinosylcytosine and hydroxyurea. Biochem. Pharmacol. 25: 73-79.

Tobey R. A., Crissman H. A., 1972. Preparation of large quantities of synchronized mammalian cells in late $\mathrm{G}_{1}$ in the pre-DNA replicative phase of the cell cycle. Exp. Cell Res. 75: 460-464.

Wa 1 ters R. A., Tobey R. A., Hildebrand C. E., 1976. Hydroxyurea does not prevent synchronized $G_{1}$ Chinese hamster cells from entering the DNA synthetic period. Biochem. Biophys. Res. Comm. 69: 212-217.

Wanka F., Moors J., Krijzer F. N. C. M., 1972. Dissociation of nucleolar DNA replication from concomitant protein synthesis in synchronous cultures of Chlorella. Biochim. Biophys. Acta 269: 153-161.

Young C. W., Schochetman G., Karnofsky D. A., 1967. Hydroxyureainduced inhibition of deoxyribonucleotide synthesis: Studies in intact cells. Cancer Res. 27: 526-534.

Author's present address:

Mgr Hanna Habdas

Research Institute of Vegetable Crops

ul. 22 Lipca 1/3; 96-100 Skierniewice, Poland 
Wbudowywanie tymidyny do jąder komórek merystematycznych korzeni cebuli $w$ obecności hydroksymocznika i jej rola $w$ odnowie aktywności mitotycznej

Streszczenie

Stwierdzono, że blok mitotyczny powodowany w merystemach korzeni cebuli działaniem hydroksymocznika jest znoszony nie tylko przez przeniesienie cebul do wody, lecz także przez dodanie do roztworów hydroksymocznika ${ }^{3} \mathrm{H}$-tymidyny lub zimnej tymidyny. W obecności hydroksymocznika zaobserwowano bardzo intensywne wbudowywanie ${ }^{3} \mathrm{H}$-tymidyny do jąder komórkowych, dające indeks znakowania $40-70 \%$. Mimo to wszystkie figury mitotyczne pojawiające się w obecności hydroksymocznika nie zawierały znacznika. Natomiast znakowane mitozy wystąpiły po przeniesieniu do wody korzeni preinkubowanych z ${ }^{3} \mathrm{H}$-tymidyną w obecności hydroksymocznika. Otrzymane wyniki wskazują, że hydroksymocznik zatrzymuje komórki merystematyczne korzeni cebuli zarówno wfazie S, jak i w fazie $\mathrm{G}_{2}$. Wzmożone wbudowywanie się ${ }^{3} \mathrm{H}$-tymidyny do jąder komórkowych w obecności hydroksymocznika wskazuje ponadto, że hydroksymocznik wybiórczo wywołuje w merystemach korzeni cebuli niedobór tymidylanu.

Wbudowywanie ${ }^{3} \mathrm{H}$-urydyny do komórek merystematycznych nie zmieniło się pod wpływem hydroksymocznika. 